\title{
EDITORIAL
}

\section{How Serotonin is Related with Lower Urinary Dysfunction}

\author{
Osamu Nishizawa
}

To view enhanced content go to www.advancesintherapy.com

Received: September 9, 2015 / Published online: September 21, 2015

(C) Springer Healthcare 2015

5-Hydroxytriptamine (5-HT; serotonin) is widely involved in human physiology [1-3]. The actions of 5-HT are mediated both by nervous and humoral activities [4-7]. The function of 5-HT has been established as a neural transmitter for the central nervous system [8]. 5-HT may evoke excitation and inhibition, and some of the effects appear to be evoked by the release of other transmitters [9]. This special issue contains three articles that focus on the contribution of 5-HT on the lower urinary tract (LUT) function. A wide variety of 5-HT receptor subtypes are variably expressed in bladder urothelium [10], smooth muscle [11], autonomic excitatory nerve terminals [12], and central pathways controlling the micturition reflex [13]. 5-HT has both physiological and pathological functions in the LUT [14].

This issue begins with a review by Matsumoto-Miyai et al. of the regulatory effects of 5-HT receptors on LUT function. The

O. Nishizawa ( $\square)$

North Alps Medical Center Azumi Hospital, Kitaazumi, Nagano, Japan

e-mail: o.nishizawa@azumi-ghp.jp

O. Nishizawa

Shinshu University Hospital, Matsumoto, Nagano, Japan function of the 5-HT varies in a species- and site-dependent manner. Numerous 5-HT receptor subtypes which present in the LUT have suitably specific expression and/or activity to represent promising drug targets for the treatment of LUT symptoms.

The second paper by Michishita et al. discusses mast cell accumulation in rat bladder with partial bladder outlet obstruction (BOO). They conclude that mast cells contain 5-HT and are more abundant locally in the subserosal layer of partial BOO rat bladders. 5-HT released from mast cells can stimulate 5-HT2 receptors on the detrusor muscle and may cause storage symptoms.

The third paper by Imamura et al. focuses on expression of 5-HT receptors in human bladders with benign prostatic hyperplasia $(\mathrm{BPH})$. The expression levels of 5-HT2B and 5-HT4 mRNA are similar between the $\mathrm{BPH}$ group and the normal group. The expression of 5-HT2A mRNA is significantly lower, while the expression of 5-HT3A and 5-HT7 mRNA is significantly higher in the BPH group than the normal group. Targeting 5-HT3A and 5-HT7 receptors in patients with $\mathrm{BPH}$ might be useful therapies for BPH related LUT symptoms. 
Finally, I would like to thank the authors of the three articles for accepting the invitation to write articles for this special issue, and for submitting and revising their manuscripts in a timely manner. I am also grateful to the Editorial board of Advances in Therapy for reviewing and approving the supplement.

\section{ACKNOWLEDGMENTS}

Sponsorship and article processing charges for this supplement were funded by a consignment study of Asahi Kasei Pharma Corporation, Tokyo, Japan. All named authors meet the International Committee of Medical Journal Editors (ICMJE) criteria for authorship for this manuscript, take responsibility for the integrity of the work as a whole, and have given final approval to the version to be published. This supplement was supported by Asahi Kasei Pharma Corp. Prior to peer review, Asahi Kasei Pharma Corp was offered the opportunity to review this paper for scientific accuracy. No changes were made as a result.

Conflict of interest. O. Nishizawa has no disclosures to declare.

\section{REFERENCES}

1. Mahar I, Bambico FR, Mechawar N, Nobrega JN. Stress, serotonin, and hippocampal neurogenesis in relation to depression and antidepressant effects. Neurosci Biobehav Rev. 2014;38:173-92.

2. Mawe GM, Hoffman JM. Serotonin signalling in the gut-functions, dysfunctions and therapeutic targets. Nat Rev Gastroenterol Hepatol. 2013;10(8):473-86.

3. Melancon MO, Lorrain D, Dionne IJ. Exercise and sleep in aging: emphasis on serotonin. Pathol Biol (Paris). 2014;62(5):276-83.
4. Daubert EA, Condron BG. Serotonin: a regulator of neuronal morphology and circuitry. Trends Neurosci. 2010;33(9):424-34.

5. de Groat WC, Griffiths D, Yoshimura N. Neural control of the lower urinary tract. Compr Physiol. 2015;5(1):327-96.

6. Jasinska AJ, Lowry CA, Burmeister M. Serotonin transporter gene, stress and raphe-raphe interactions: a molecular mechanism of depression. Trends Neurosci. 2012;35(7):395-402.

7. Camilleri M. Physiological underpinnings of irritable bowel syndrome: neurohormonal mechanisms. J Physiol. 2014;592(Pt 14):2967-80.

8. Ciranna L. Serotonin as a modulator of glutamateand GABA-mediated neurotransmission: implications in physiological functions and in pathology. Curr Neuropharmacol. 2006; 4(2):101-14.

9. Murano M, Saitow F, Suzuki H. Modulatory effects of serotonin on glutamatergic synaptic transmission and long-term depression in the deep cerebellar nuclei. Neuroscience. 2011;172:118-28.

10. Ochodnický P, Humphreys S, Eccles R, Poljakovic M, Wiklund P, Michel MC. Expression profiling of G-protein-coupled receptors in human urothelium and related cell lines. BJU Int. 2012;110(6 Pt B):E293-300.

11. Kaumann AJ, Frenken M, Posival H, Brown AM. Variable participation of 5-HT1-like receptors and 5-HT2 receptors in serotonin-induced contraction of human isolated coronary arteries. 5-HT1-like receptors resemble cloned 5-HT1D beta receptors. Circulation. 1994;90(3):1141-53.

12. Dougherty JJ, Nichols RA. Cross-regulation between colocalized nicotinic acetylcholine and 5-HT3 serotonin receptors on presynaptic nerve terminals. Acta Pharmacol Sin. 2009;30(6):788-94.

13. Thor KB, Katofiasc MA, Danuser H, Springer J, Schaus JM. The role of 5-HT(1A) receptors in control of lower urinary tract function in cats. Brain Res. 2002;946(2):290-7.

14. Burgard EC, Fraser MO, Thor KB. Serotonergic modulation of bladder afferent pathways. Urology. 2003;62(4 Suppl 1):10-5. 